\title{
ANALISIS PENGARUH BAURAN PEMASARAN TERHADAP TINGKAT PENJUALAN
}

\author{
Hendy Eka Sumarga', Mulia Alim² \\ Universitas Muhammadiyah Tangerang \\ hendi_es@umt.ac.id', alimI7mt@gmail.com²
}

\begin{tabular}{|c|c|}
\hline Keyword & Abstract \\
\hline $\begin{array}{l}\text { Products, Prices, Places, Promotions, } \\
\text { Sales }\end{array}$ & $\begin{array}{l}\text { One early indicator to determine the condition of the progress of product } \\
\text { marketing is through observation of the amount of product marketing } \\
\text { results that have been done of the company. In institutions engaged in } \\
\text { companies that produce refined products and the manufacturer is } \\
\text { known from a list of sales results in the marketing department. This } \\
\text { indicator is not always right but as an initial indication, can be used as } \\
\text { indicators to examine further by way of scientific research. The purpose } \\
\text { of this study was to determine the effect simultaneously and partially of } \\
\text { the marketing mix that includes variable Products (XI), Price (X2), } \\
\text { Place (X3), and Promotion (X4) on the level of sales at Rumah Makan } \\
\text { Ayam Gantung Bandung (Y), and to determine the marketing mix most } \\
\text { dominant influence. Methodology The study was conducted by } \\
\text { descriptive method, which aims to explain (explanatory), the influence of } \\
\text { variables independent of the independent variable. }\end{array}$ \\
\hline
\end{tabular}

C2016 JMB, All right reserved

\section{PENDAHULUAN}

Peningkatan kemampuan pemasaran produk suatu unit usaha merupakan suatu hal yang sangat penting untuk pengembangan perusahaan, oleh sebab itu banyak strategi yang diterapkan oleh perusahaan tidak hanya dari sisi kuantitas dan kualitas produk saja yang menjadi fokus perhatian untuk tercapainya tujuan pemasaran suatu produk dalam hal ini adalah bagaimana perusahaan tersebut mampu melakukan peningkatan penjualannya. Selain faktor kuatitas dan kualitas produk terdapat faktor penentu lainnya yang berpengaruh besar terhadap kemampuan peningkatan penjualan, yaitu bagaimana perusahaan dapat dengan tepat menerapkan strategi penetapan harga dengan baik, melakukan strategi promosi dengan baik, dan kemampuan menempatkan keberadaan letak atau lokasi perusahaan yang strategis.

$\mathrm{Di}$ bidang pemasaran suatu produk, pengenalan produk suatu perusahaan, harga, promosi serta luasnya daerah jangkauan pemasaran produk memegang peranan yang penting dalam upaya peningkatan penjualan.

Pada saat konsumen bermaksud membeli produk, calon konsumen digerakkan oleh keinginan akan kebutuhan terhadap produk tersebut, yang pada umumnya konsumen mempunyai perilaku membeli terhadap produkproduk yang sering dipromosikan atau yang sudah familier dengan harga yang terjangkau dan mudah untuk didapatkan. Namun apabila suatu produk tidak familier di telinga konsumen, harga yang tinggi serta tidak mudah didapat tidak akan menjadi pilihan bagi konsumen. Sehingga kedua hal tersebut merupakan hal-hal yang harus dipikirkan dan dituangkan dalam perilaku management, karena hal tersebut dapat berpengaruh terhadap peningkatan penjualan suatu produk.

Persaingan yang ketat dalam pasar mengakibatkan setiap produsen berusaha untuk selalu menekankan pentingnya produk atau jasa yang mempunyai symbolic image, oleh karena itu dalam lingkungan bisnis yang hiperkompotitif 
seperti saat ini, memposisikan brand image dan quality image dengan baik merupakan suatu hal yang sangat penting untuk diperhitungkan.

Perusahaan tidak hanya dituntut untuk memproduksi barang yang dibutuhkan dan diinginkan konsumen. Tetapi perusahaan juga harus mengetahui bagaimana menyajikan atau menawarkan produk serta memberikan jaminan kualitas kepada konsumen dengan jalan melakukan promosi yang tepat. Tujuannya agar produk yang ditawarkan dapat menjadi pilihan pertama atau top mind di benak konsumen, yang pada akhirnya produk dapat berkenan di hati konsumen (heart share), dan konsumen selalu berimajinasi tentang produk tersebut. Semakin besar mind share, maka diharapkan semakin besar pula market share.

\section{TINJAUAN PUSTAKA}

\section{Bauran Pemasaran}

Salah satu bagian yang juga penting dalam pemasaran yaitu bauran pemasaran, bauran pemasaran merupakan salah satu konsep utama dalam pemasaran modern.

Menurut Philip Kotler (2000:82), Bauran promosi adalah tugas perubahan dalam mendistribusikan total anggaran promosi melalui lima alat promosi yaitu periklanan, promosi penjualan, pemasaran langsung, hubungan masyarakat dan tenaga penjualan.

Menurut Husein Umar (2003:77), bauran pemasaran merupakan kebijakan pemasaran (marketing mix) yang terdiri dari 4 (empat) komponen, yaitu :

a. Produk (product)

Produk merupakan kombinasi barang dan jasa yang ditawarkan oleh perusahaan kepada pasar sasaran. Pengembangan sebuah produk mengharuskan perusahaan untuk menetapkan manfaat-manfaat apa yang akan diberikan oleh produk tersebut. Manfaat tersebut dikomunikasikan dan hendaknya dipenuhi oleh atribut produk.

b. Harga (price)

Harga adalah jumlah uang yang harus dibayar oleh pelanggan untuk memperoleh produk. Keputusan mengenai penetapan harga dipengaruhi oleh beberapa faktor, yaitu faktor internal perusahaan maupun faktor eksternal perusahaan.

Dalam hal faktor internal perusahaan, keputusan harga disesuaikan dengan sasaran pemasaran, misalnya : untuk bertahan hidup, memaksimalkan laba jangka pendek, memaksimalkan pangsa pasar atau kepemimpinan mutu produk. Keputusan harga pasar disesuaikan dengan strategi marketing mix, dimana manajemen harus mempertimbangkannya sebagai satu keseluruhan.

Dalam hal faktor eksternal perusahaan, dapat dijelaskan sebagai berikut : harga pasar dan permintaan konsumen merupakan plafon harga (harga tertinggi). Konsumen akan membandingkan harga suatu produk atau jasa dengan manfaat yang dimiliki. Oleh karena itu, sebelum menetapkan harga, harus dipahami dulu hubungan antara harga dan permintaan terhadap produk tersebut. Faktor eksternal lainnya adalah kondisi ekonomi, seperti : tingkat inflasi, biaya bunga, resesi, dan keputusan Pemerintah.

c. Distribusi (place)

Distribusi termasuk aktivitas perusahaan untuk membuat produk tersedia bagi konsumen sasarannya. Dalam mendesain suatu sistem saluran distribusi diperlukan analisis kebutuhan layanan konsumen, penetapan sasaran dan kendala saluran, identifikasi alternatif saluran yang utama yang berhubungan dengan jenis perantara, jumlah perantara dan tanggung jawab anggota saluran serta evaluasinya.

d. Promosi (promotion)

Promosi berarti aktivitas yang mengkomunikasikan keunggulan produk dan membujuk pelanggan sasaran untuk membelinya. Program pemasaran efektif mencampurkan semua elemen bauran pemasaran ke dalam program terkoordinasi yang dirancang untuk mencapai sasaran pemasaran perusahaan dengan menyerahkan nilai kepada konsumen. Jadi, perusahaan yang sukses adalah perusahaan yang dapat memenuhi kebutuhan pelanggan secara ekonomis dan mudah serta dengan komunikasi yang efektif.

\section{Hipotesis}

Sebagaimana kita ketahui bahwa banyak bisnis rumah makan yang dibangun dan didirikan dengan berbagai macam bentuk konsep yang merupakan ciri khas bagi rumah makan tersebut, semua itu dilakukan dalam rangka bagaimana produk-produk yang dikeluarkan oleh rumah makan tersebut dapat diminati oleh konsumen yang datang sehingga dapat meningkatkan volume penjualannya.

Adapun upaya yang sering dilakukan adalah hanya dengan menggunakan media promosi, namun terkadang dilupakannya 
beberapa faktor penting lainnya seperti produk, harga dan tempat yang memiliki peranan yang tidak kalah pentingnya dalam upaya meningkatkan penjualan.

$\mathrm{Hal}$ ini yang kemudian menjadi dasar pertimbangan untuk mengkorelasikan kedalam bentuk kajian penelitian yang menganalisis tentang pengaruh produk, harga, tempat dan promosi terhadap tingkat penjualan.

Sebelum digunakan sebagai dasar kesimpulan, persamaan regresi yang diperoleh dan telah memenuhi asumsi regresi melalui pengujian diatas perlu diuji koefisien regresinya baik secara simultan untuk melihat apakah model yang diperoleh dan koefisien regresinya dapat dikatakan bermakna secara statistik agar dapat diambil kesimpulan secara umum untuk populasi penelitian.

Tujuan pengujian ini digunakan untuk melihat apakah variabel - variabel bebas secara bersama-sama mampu mempengaruhi variabel terikat, Adapun hipotesis yang akan diuji adalah : Ho : $\beta I, \beta 2, \beta 3, \beta 4=0$ Tidak terdapat pengaruh yang signifikan antara Produk (XI), Harga (X2), Tempat (X3), Promosi $(X 4)$, , Terhadap Tingkat Penjualan.

$\mathrm{HI}: \beta \mathrm{I}, \beta 2, \beta 3, \beta 4 \neq 0$ Terdapat pengaruh yang sigifikan antara produk (XI), Harga (X2), Tempat (X3), Promosi (X4), Terhadap Tingkat Penjualan.

\section{METODE PENELITIAN}

Model penelitian yang digunakan dalam penelitian ini adalah penelitian deskriptif, karena penelitian ini dilakukan dengan mengkaji dan menganalisis secara logis masalah yang telah dirumuskan dengan berdasarkan teori dan fakta di lapangan, kemudian hasilnya dideskripsikan secara sistematis sebagai variabel-variabel dalam penelitian yang memperlihatkan pengaruh sebagaimana adanya.

Teknik pengambilan sampel yang digunakan dalam penelitian ini adalah purposive sampling dan untuk kemudian diolah menggunakan metode Skala Likert yang sebelumnya diperoleh dari pengumpulan data menggunakan kuesioner, wawancara dan observasi. Sampel responden yang diambil adalah para konsumen Rumah Makan Ayam Gantung Bandung di Kota Tangerang sebanyak 60 responden/ Konsumen. Variabel yang digunakan dalam penelitian ini adalah Produk (XI), Harga (X2), Tempat (X3), Promosi (X4), Penjualan (y).

\section{HASIL PENELITIAN DAN \\ PEMBAHASAN}

\section{Uji Validitas}

Uji Validasi dilakukan untuk mengukur pernyataan yang ada dalam kuesioner, Validasi sutau data tercapai jika pernyataan tersebut mampu mengungkapkan apa yang akan dinyatakan, Angka yang dipergunakan sebagai pembanding untuk melihat valid tidaknya suatu item, adalah 0,3 dimana item yang memiliki korelasi diatas 0,3 dikategorikan item valid, sedangkan item dibawah 0,3 dikategorikan tidak valid dan akan disisihkan dari analisis selanjutnya.

Tabel I. Hasil Uji Validasi Instrumen (XI)

\begin{tabular}{|c|c|c|c|}
\hline $\begin{array}{c}\text { No. } \\
\text { Kuesioner }\end{array}$ & $\begin{array}{c}\text { Nilai } \\
\text { Korelasi }\end{array}$ & $\begin{array}{c}\text { Nilai } \\
\text { Kritis }\end{array}$ & Keterangan \\
\hline I & 0,529 & 0.3 & Valid \\
\hline 2 & 0,547 & 0.3 & Valid \\
\hline 3 & 0,578 & 0.3 & Valid \\
\hline 4 & 0,679 & 0.3 & Valid \\
\hline 5 & 0,486 & 0.3 & Valid \\
\hline 6 & 0,605 & 0.3 & Valid \\
\hline
\end{tabular}

Tabel 2. Hasil Uji Validasi Instrumen (X2)

\begin{tabular}{|c|c|c|c|}
\hline $\begin{array}{c}\text { No. } \\
\text { Kuesioner }\end{array}$ & $\begin{array}{c}\text { Nilai } \\
\text { Korelasi }\end{array}$ & $\begin{array}{c}\text { Nilai } \\
\text { Kritis }\end{array}$ & Keterangan \\
\hline I & 0,667 & 0.3 & Valid \\
\hline 2 & 0,789 & 0.3 & Valid \\
\hline 3 & 0,687 & 0.3 & Valid \\
\hline 4 & 0,504 & 0.3 & Valid \\
\hline 5 & 0,786 & 0.3 & Valid \\
\hline 6 & 0,609 & 0.3 & Valid \\
\hline
\end{tabular}

Tabel 3. Hasil Uji Validasi Instrumen (X3)

\begin{tabular}{|c|c|c|c|}
\hline $\begin{array}{c}\text { No. } \\
\text { Kuesioner }\end{array}$ & $\begin{array}{c}\text { Nilai } \\
\text { Korelasi }\end{array}$ & $\begin{array}{c}\text { Nilai } \\
\text { Kritis }\end{array}$ & Keterangan \\
\hline I & 0.419 & 0.3 & Valid \\
\hline 2 & 0.581 & 0.3 & Valid \\
\hline 3 & 0.675 & 0.3 & Valid \\
\hline 4 & 0.667 & 0.3 & Valid \\
\hline 5 & 0.758 & 0.3 & Valid \\
\hline 6 & 0.570 & 0.3 & Valid \\
\hline
\end{tabular}

Tabel 4. Hasil Uji Validasi Instrumen (X4)

\begin{tabular}{|c|c|c|c|}
\hline $\begin{array}{c}\text { No. } \\
\text { Kuesioner }\end{array}$ & $\begin{array}{c}\text { Nilai } \\
\text { Korelasi }\end{array}$ & $\begin{array}{c}\text { Nilai } \\
\text { Kritis }\end{array}$ & Keterangan \\
\hline I & 0,842 & 0.3 & Valid \\
\hline 2 & 0,592 & 0.3 & Valid \\
\hline 3 & 0,631 & 0.3 & Valid \\
\hline 4 & 0,642 & 0.3 & Valid \\
\hline 5 & 0,821 & 0.3 & Valid \\
\hline 6 & 0,677 & 0.3 & Valid \\
\hline
\end{tabular}


Tabel 5. Hasil Uji Validasi Instrumen (Y)

\begin{tabular}{|c|c|c|c|}
\hline $\begin{array}{c}\text { No. } \\
\text { Kuesioner }\end{array}$ & $\begin{array}{c}\text { Nilai } \\
\text { Korelasi }\end{array}$ & $\begin{array}{c}\text { Nilai } \\
\text { Kritis }\end{array}$ & Keterangan \\
\hline 1 & 0,680 & 0.3 & Valid \\
\hline 2 & 0,685 & 0.3 & Valid \\
\hline 3 & 0,425 & 0.3 & Valid \\
\hline 4 & 0,776 & 0.3 & Valid \\
\hline 5 & 0,575 & 0.3 & Valid \\
\hline 6 & 0,476 & 0.3 & Valid \\
\hline 7 & 0,690 & 0.3 & Valid \\
\hline 8 & 0,654 & 0.3 & Valid \\
\hline
\end{tabular}

\section{Uji Reliabilitas}

Tabel 6. Reliabilitas

\begin{tabular}{|l|l|}
\hline \multicolumn{1}{|c|}{ Variabel } & \multicolumn{1}{c|}{ Alpha } \\
\hline Produk & 0,7016 \\
\hline Harga & 0,7040 \\
\hline Tempat & 0,7535 \\
\hline Promosi & 0,7523 \\
\hline Penjualan & $0,755 \mathrm{I}$ \\
\hline
\end{tabular}

Dari hasil perhitungan reliabilitas diperoleh besar koefisien Alpha untuk variabel $X 1$ sebesar 0.7016 , variabel $X 2$ sebesar 0,7040 variabel $X 3$ sebesar 0.7535 , Variabel $X 4$ sebesar 0.7523 , variabel $X 5$ sebesar 0.7443 dan untuk variabel $Y$ sebesar $0.755 \mathrm{I}$ Berdasarkan hasil uji reliabilitas menunjukan bahwa semua variabel tersebut dapat dikatakan reliabel, (Nilai koefisien reliabilitis minimal $0,70-0,80$ )

\section{Uji Normalitas.}

Dari hasil pengujian normalitas pada model regresi ini menunjukan bahwa nilai residual dai model berdistribusi normal. $\mathrm{Hal}$ ini dapat dilihat dari hasil pengujian normalitas menggunakan uji kolmogorov-smirnov dimana nilai probabilitas (Asymp.sig.) sebesar 0,662 lebih besar dari 0,05.

\section{Tabel 7. Uji Normalitas Data}

One-Sample Kolmogorov-Smirnov Test

\begin{tabular}{|ll|r|r|r|r|r|r|}
\hline & & \multicolumn{1}{|c|}{$\mathrm{X} 1$} & \multicolumn{1}{|c|}{$\mathrm{X} 2$} & \multicolumn{1}{|c|}{$\mathrm{X} 3$} & \multicolumn{1}{|c|}{$\mathrm{X} 4$} & $\mathrm{X} 5$ & $\mathrm{Y}$ \\
\hline $\mathrm{N}$ & & 30 & 30 & 30 & 30 & 30 & 30 \\
Normal Parametersa,b & Mean & 33.70 & 24.40 & 19.63 & 24.40 & 16.60 & 30.40 \\
& Std. Deviation & 3.186 & 2.061 & 1.377 & 2.222 & 1.734 & 2.594 \\
Most Extreme & Absolute & .163 & .148 & .195 & .195 & .158 & .128 \\
Differences & Positive & .129 & .145 & .195 & .121 & .109 & .128 \\
& Negative & -.163 & -.148 & -.118 & -.195 & -.158 & -.072 \\
Kolmogorov-Smirnov Z & & .895 & .810 & 1.068 & 1.069 & .865 & .701 \\
Asymp. Sig. (2-tailed) & & .399 & .528 & .204 & .203 & .443 & .710 \\
\hline
\end{tabular}

a. Test distribution is Normal.

b. Calculated from data.

\section{Multikolinearitas}

Terjadi atau tidaknya multikolinearitas dapat dilihat dari nilai Variance Inflation Factors (VIF), Apabila nilai VIF untuk variabel bebas lebih dari 10, Dari hasil perhitungan terlihat nilai
VIF lebih kecil dari 10 sehingga dapat disimpulkan tidak terjadi kolinearitas yang tinggi antara variabel bebas dalam persamaan regresi yang diperoleh.

Tabel 8. Uji Multikolinieritas

\begin{tabular}{|c|c|c|c|c|c|c|c|c|c|c|c|c|c|}
\hline \multicolumn{14}{|c|}{ Coefficients } \\
\hline \multirow[b]{2}{*}{ Mode } & & \multicolumn{2}{|c|}{$\begin{array}{l}\text { Unstandardized } \\
\text { Coefficients }\end{array}$} & \multirow{2}{*}{$\begin{array}{c}\begin{array}{c}\text { Standardized } \\
\text { Coefficients }\end{array} \\
\text { Beta }\end{array}$} & \multirow[b]{2}{*}{$t$} & \multirow[b]{2}{*}{ Sig. } & \multicolumn{2}{|c|}{$95 \%$ Confidence Interval for B } & \multicolumn{3}{|c|}{ Correlations } & \multicolumn{2}{|c|}{ Collinearity Statistics } \\
\hline & & $\mathrm{B}$ & Std. Error & & & & Lower Bound & Upper Bound & Zero-order & Partial & Part & Tolerance & VIF \\
\hline & (Constant) & 29.340 & 14.349 & & 2.045 & .052 & -.274 & 58.954 & & & & & \\
\hline & $X 1$ & $8.328 \mathrm{E}-02$ & .174 & .102 & .480 & .636 & -.275 & .441 & .128 & .098 & .096 & .881 & 1.136 \\
\hline & $\times 2$ & .106 & .326 & .085 & .326 & .747 & -.567 & .780 & .104 & .066 & .065 & .595 & 1.681 \\
\hline & $\times 3$ & -167 & .387 & -.089 & -.432 & .669 & -.966 & .631 & -112 & -.088 & .086 & .948 & 1.055 \\
\hline & $X 4$ & 4.256E-02 & .300 & .036 & .142 & .888 & -.577 & .662 & .085 & .029 & .028 & .605 & 1.653 \\
\hline & $\times 5$ & -.126 & .325 & -.084 & -389 & .700 & -.796 & .543 & -.071 & -.079 & -.078 & .850 & 1.177 \\
\hline
\end{tabular}

a. Dependent Variable: $Y$

\section{Heterokedastisitas}

Heterokedastisitas merupakan indikasi bahwa varian antara residual tidak homogen yang mengakibatkan nilai taksiran yang diperoleh tidak lagi efisien, Apabila terdapat koefisien korelasi dari masing-masing variabel bebas yang signifikan menunjukan adanya heterokedastisitas, pada tabel berikut terlihat nilai t-hitung dan $p$ value untuk masing-masing variabel bebas. 
Tabel 9. Uji Heterokedastisitas

\begin{tabular}{lccl}
\hline \multicolumn{1}{c}{$\begin{array}{c}\text { Variabel } \\
\text { Bebas }\end{array}$} & r & Sig. & \multicolumn{1}{c}{ Keputusan } \\
\hline Produk $(X \mid)$ & $-0,160$ & 0,165 & Tidak Signifikan \\
Harga $(X 2)$ & $-0,025$ & 0,840 & Tidak Signifikan \\
Tempat $(X 3)$ & $-0,115$ & 0,335 & Tidak Signifikan \\
Promosi $(X 4)$ & $-0,155$ & 0,186 & Tidak Signifikan \\
\hline
\end{tabular}

Dari hasil yang diperoleh pada tabel 9 mempunyai varians yang sama terlihat hasil dari pengujian untuk semua korelasi variabel bebas dengan harga mutlak dari residual (error) tidak signifikan ( $p$-value lebih besar dari $\alpha=0,05)$ dapat disimpulkan bahwa residual (error) dalam persamaan regresi (homoskedastisitas).

\section{Pengaruh Bauran Pemasaran terhadap Tingkat Penjualan.}

Hasil perhitungan persamaan regresi dengan menggunakan SPSS dapat dilihat pada tabel berikut ini.

Tabel I0. Tabel Koefisien Regresi

\begin{tabular}{lcc}
\hline \multicolumn{1}{c}{ Variabel Bebas } & Koefisien & Std. Error \\
\hline Konstanta & $-3,402$ & 3,289 \\
Produk $(X I)$ & 0,253 & 0,111 \\
Harga $(X 2)$ & 0,367 & 0,130 \\
Tempat $(X 3)$ & 0,405 & 0,145 \\
Promosi $(X 4)$ & 0,419 & 0,122 \\
\hline
\end{tabular}

Variabel terikat : Keputusan Penggunaan.

Hasil Output SPSS diatas dapat dituliskan kedalam persamaan regresi sebagai berikut : $Y=-3,402+0,253 X I+0,367 X 2+0,405 X 3$ $+0,419 \times 4$

Persamaan diatas dapat diinterpretasikan sebagai berikut :

a. Konstanta sebesar 3,402 merupakan perpotongan garis regresi dengan sumbu $Y$ yang menunjukan skor keinginan membeli ketika semua variabel bebasnya, yaitu Produk (XI), Harga (X2), Tempat (X3), dan Promosi $(X 4)$, sama dengan nol (0).

b. Variabel Produk (XI) memiliki koefisien regresi positif, artinya bahwa apabila variabel produk (XI) meningkat sebesar satu satuan maka tingkat penjualan ( $Y$ ) akan mengalami kenaikan sebesar nilai koefisien regrisinya sebesar 0,253 dengan asumsi variabel bebas lainnya tetap.

c. Variabel Harga (X2) memiliki koefisien regresi positif, artinya bahwa apabila variabel harga $(X 2)$ meningkat sebesar satu satuan maka tingkat penjualan (Y) akan mengalami kenaikan sebesar nilai koefisien regrisinya sebesar 0,367 dengan asumsi variabel bebas lainnya tetap.

d. Variabel Tempat (X3) memiliki koefisien regresi positif, artinya bahwa apabila tempat (X3) meningkat sebesar satu satuan maka tingkat penjualan (Y) akan mengalami kenaikan sebesar nilai koefisien regrisinya sebesar 0,405 dengan asumsi variabel bebas lainnya tetap.

e. Variabel Promosi (X4), memiliki koefisien regresi positif, artinya bahwa apabila variabel promosi $(X 4)$, meningkat sebesar satu satuan maka tingkat penjualan (Y) akan mengalami kenaikan sebesar nilai koefisien regrisinya sebesar 0,419 dengan asumsi variabel bebas lainnya tetap.

Tabel I I. Pengujian F hitung

\begin{tabular}{lccccc}
\hline $\begin{array}{c}\text { Sumber } \\
\text { variasi }\end{array}$ & $\begin{array}{c}\text { Jumlah } \\
\text { kuadrat }\end{array}$ & db & $\begin{array}{c}\text { Rataan junlah } \\
\text { kuadrat }\end{array}$ & F-hitung & Sig. \\
\hline Regressi & $\mathrm{I} 19.930$ & 4 & 32.321 & $12.31 \mathrm{I}$ & 0.000 \\
Residual & 196.860 & 55 & 2.809 & & \\
Total & 395.890 & 59 & & & \\
\hline
\end{tabular}


Dari tabel II diatas dapat dilihat bahwa F-hitung adalah $12.3 \mathrm{I}$ I dan diperoleh nilai $\mathrm{F}$ dari tabel untuk $\alpha=0,05$ dengan derajat bebas (4: 55) sebesar 2,53 karena F-hitung lebih besar dari $F$ tabel, maka Ho ditolak, artinya dengan tingkat kepercayaan $95 \%$ dapat disimpulkan bahwa terdapat pengaruh yang signifikan dari variabel Produk (XI), Harga (X2), Tempat (X3), dan Promosi (X4), terhadap tingkat penjualan (y).

Tabel I2. Pengujian Hipotesis $\mathbf{t}$

\begin{tabular}{|l|c|c|c|c|}
\hline \multicolumn{1}{|c|}{ Variabel Bebas } & Koefisien & $\begin{array}{c}\text { Std. } \\
\text { Error }\end{array}$ & t-hitung & p-Value \\
\hline Konstanta & -3.402 & 3.289 & -1.035 & 0.306 \\
Produk (XI) & 0.253 & 0.111 & 3.146 & 0.042 \\
Harga $(X 2)$ & 0.367 & 0.130 & 3.310 & 0.007 \\
Tempat (X3) & 0.404 & 0.145 & 2.876 & 0.005 \\
Promosi (X4) & 0.419 & 0.122 & 2.769 & 0.040 \\
\hline
\end{tabular}

Dari perhitungan pada tabel diatas diperoleh nilai t-hitung untuk variabel bebas produk sebesar 3.146 dan tabel t-student dengan $\alpha=0.05$ dan derajat bebas $=60-4-1=$ 55 untuk pengujian dua sisi diperoleh nilai ttabel.

Kriteria pengujian dua sisi adalah Tolak Ho jika t hitung $>$ t-tabel atau t-hitung < negatif ttabel Karena nilai t-hitung untuk variabel bebas produk sebesar 3.146 lebih besar dari t-tabel = 2.0003 maka pada tingkat kesalahan $5 \% \mathrm{Ho}$ ditolak, dan dapat disimpulkan bahwa dengan tingkat kepercayaan $95 \%$ terdapat pengaruh yang nyata produk $(X I)$ terhadap tingkat penjualan (y).

Besarnya pengaruh produk ini banyak dipengaruhi oleh :

I. Kwalitas rasa yang diberikan oleh rumah makan ayam gantung

2. Banyak alternatif pemilihan menu yang disediakan

3. Kecepatan dalam penyajian

Dari perhitungan pada tabel 12 diatas diperoleh nilai t-hitung untuk variabel bebas harga sebesar 3.310 dan tabel t-student dengan $\alpha=0.05$ dan derajat bebas $=60-4-1=55$ untuk pengujian dua sisi diperoleh nilai t-tabel .

Kriteria pengujian dua sisi adalah Tolak Ho jika $\mathrm{t}$ hitung $>\mathrm{t}$-tabel atau $\mathrm{t}$ hitung $<$ negatif $\mathrm{t}$ tabel, Karena nilai t-hitung untuk variabel bebas harga sebesar 3.310 lebih besar dari t-tabel = 2.0003 maka pada tingkat kesalahan $5 \%$ Ho ditolak, dan dapat disimpulkan bahwa dengan tingkat kepercayaan $95 \%$ terdapat pengaruh yang nyata harga (X2) terhadap tingkat penjualan $(y)$.

Sementara itu besarnya pengaruh Harga

banyak dipengaruhi oleh :

I. Harga untuk setiap menu makanan sangat kompetitif dengan harga menu-menu yang sama pada rumah makan lain.
2. Harga untuk setiap menu makanan sangat sesuai dengan rasa dan kualitas makanan

Dari perhitungan pada tabel 12 diperoleh nilai t-hitung untuk variabel bebas tempat sebesar 2.876 dan tabel t-student dengan $\alpha=$ 0.05 dan derajat bebas $=60-4-I=55$ untuk pengujian dua sisi diperoleh nilai t-tabel.

Kriteria pengujian dua sisi adalah Tolak Ho jika $\mathrm{t}$ hitung $>\mathrm{t}$-tabel atau t-hitung < negatif $\mathrm{t}$ tabel, Karena nilai t-hitung untuk variabel bebas tempat sebesar 2.876 lebih besar dari t-tabel = 2.0003 maka pada tingkat kesalahan $5 \% \mathrm{Ho}$ ditolak, dan dapat disimpulkan bahwa dengan tingkat kepercayaan $95 \%$ terdapat pengaruh yang nyata tempat $(X 3)$ terhadap tingkat penjualan $(y)$

Besarnya pengaruh Tempat banyak dipengaruhi oleh :

I. Tempat dianggap sudah cukup strategis

2. Tempat parkir luas dan terdapat tempat sholat (Musholla)

3. Kenyaman tempat mendukung suasana konsumen untuk menyatap makanan

4. Terdapat tempat bermain untuk anak

5. Kemanan tempat terjamin

Sementara untuk variable (X4) Promosi Dari perhitungan pada tabel 4.9 diperoleh nilai thitung untuk variabel bebas promosi sebesar 2.769 dan tabel t-student dengan $\alpha=0.05$ dan derajat bebas $=60-4-\mathrm{I}=55$ untuk pengujian dua sisi diperoleh nilai t-tabel

Kriteria pengujian dua sisi adalah Tolak Ho jika t hitung $>$ t-tabel atau t-hitung $<$ negatif $\mathrm{t}$ tabel, Karena nilai t-hitung untuk variabel bebas promosi sebesar 2.769 lebih besar dari t-tabel $=2.0003$ maka pada tingkat kesalahan 5 \% Ho ditolak, dan dapat disimpulkan bahwa dengan tingkat kepercayaan $95 \%$ terdapat pengaruh yang nyata promosi (X4) terhadap tingkat penjualan $(y)$. 
Besarnya pengaruh Promosi ini banyak

dipengaruhi oleh :

I. Iklan yang ditayangkan pada media cetak atau surat kabar lokal

2. Informasi yang diberikan konsumen kepada rekan atau konsuemne lain setelah mereka merasakan kepuasan yang diberikan oleh pihak rumah makan baik itu rasa, harga dan temapt yang nyaman.

Sedangkan faktor lain yang harus selalau ditingkatkan yang berkaitan dengan bauran pemasaran mulai dari produk, Harga, Tempat dan Promosi adalah :

I. Menjaga kualitas rasa

2. Selalu memberikan alternatif menu pilihan

3. Memperbanyak pilihan - pilihan menu baru

4. Meningkatkan kenyaman dan keamanan tempat dan menambah wahana atau tempat penunjang lain. Misalkan Tempat pijat, Hotspot gratis, counter souvenir dan lain-lain.

5. Menambah alat promosi dengan memaksimalkan media lokal seperti radio, surat kabar, brosur, internet dan lain - lain.

\section{DAFTAR PUSTAKA}

Arikunto Suharsimi, 2000. Manajemen Penelitian, Rineka Cipta, Jakarta.

Arif Pratisto. 2000. Cara Mengatasi Masalah Statistik Dan Rancangan Percobaan Dengan SPSS 12". Elek Media Komputindo, Jakarta.

Bayu Swastha, Handoko T Hani 2000. Manajemen Pemasaran : Analisa Perilaku konsumen, Edisi Pertama. BPFE-Yogyakarta, Yogyakarta.

Daryanto S.S. 1997. Kamus Bahasa Indonesia Lengkap, cetakan pertama, Surabaya : Apollo,

Fandy Tjiptono. 200. Strategi Pemasaran, edisi 2, Andi, Yogyakarta.

H. Lovelock, Christopher, K. Wright, Lauren. 2005. Manajemen Pemasaran Jasa. PT. Indeks Kelompok Gramedia, Jakarta.

Hermanwan Kertajaya. 2002. Dimensi Pemasaran, Pustaka Pelajar, Jakarta.

Husein Umar. 2003. Metode Riset Bisnis cetakan 2, Gramedia Pustaka, Jakarta. 